\title{
Pengaruh Ukuran Perusahaan, Return On Asset, Debt To Asset Ratio dan Komite Audit terhadap Penghindaran Pajak
}

\author{
Suryani ${ }^{1 *}$ \\ ${ }^{1}$ Akuntansi; Universitas Budi Luhur; Jl. Ciledug Raya, RT.10/RW.2, Petukangan Utara, \\ Kec. Pesanggrahan, Kota Jakarta Selatan; e-mail: suryani@budiluhur.ac.id \\ * Korespondensi: e-mail: suryani@budiluhur.ac.id
}

Diterima: 30 April 2020; Review: 04 Mei 2020; Disetujui: 30 Mei 2020

Cara sitasi: Suryani. 2020. Pengaruh Ukuran Perusahaan, Return On Asset, Debt to Asset Ratio dan Komite Audit terhadap Penghindaran Pajak. Jurnal Online Insan Akuntan. Vol. 5(1): 83-98.

\begin{abstract}
Abstrak: Pajak merupakan salah satu sumber penerimaan Negara yang paling besar dalam pembiayaan negara. Semakin besar penerimaan pajak maka semakin baik bagi keberlangsungan suatu negara. Sebaliknya bagi perusahaan sebagai wajib pajak, pajak merupakan biaya yang mengurangi laba perusahaan sehingga semaksimal mungkin perusahaan akan melakukan cara agar membayar pajak dengan nilai yang minimal. Salah satu cara yang dapat digunakan oleh perusahaan adalah dengan melakukan penghindaran pajak (tax avoidance). Tujuan dari penelitian ini adalah untuk mengetahui apakah ada pengaruh dari ukuran perusahaan, return on asset, debt to asset ratio dan komite audit terhadap penghindaran pajak. Data yang diteliti diperoleh dari laporan keuangan tahunan perusahaan manufaktur yang terdaftar di Bursa Efek Indonesia periode 2014-2018. Metode pemilihan sampel yang digunakan adalah metode purposive sampling dengan teknik analisis adalah regresi linier berganda. Populasi dalam penelitian ini adalah 144 perusahaan manufaktur dengan total sampel sebanyak 45 perusahaan. Hasil penelitian menunjukkan bahwa ukuran perusahaan dan return on asset berpengaruh negatif terhadap penghindaran pajak, sedangkan debt to asset ratio dan komite audit tidak berpengaruh terhadap persistensi laba.
\end{abstract}

Kata kunci: penghindaran pajak, ukuran perusahaan, return on asset, debt to asset ratio, komite audit

\begin{abstract}
Taxes are one of the largest sources of state revenue in state financing. The greater the tax revenue, the better for the sustainability of a country. Conversely for companies as taxpayers, tax is a cost that reduces company profits so that as much as possible the company will do the way to pay taxes with a minimum value. One way that can be used by companies is to avoid tax (tax avoidance). The purpose of this study is to determine whether there is an influence of company size, return on assets, debt to asset ratio and audit committee on tax avoidance. The data studied were obtained from the annual financial statements of manufacturing companies listed on the Indonesia Stock Exchange in the 20142018 period. The sample selection method used is the purposive sampling method with the analysis technique is multiple linear regression. The population in this study were 144 manufacturing companies with a total sample of 45 companies. The results showed that company size and return on assets negatively affect tax avoidance, while debt to asset ratio and audit committee have no effect on earnings persistence.
\end{abstract}

Keywords: tax avoidance, size, return on asset, debt to asset ratio and audit committee 


\section{Pendahuluan}

Pajak merupakan sumber pendanaan terbesar bagi negara. Hampir semua negara memungut pajak dari rakyatnya demi kelangsungan hidup negara. Berdasarkan publikasi Laporan Kinerja Direktorat Jenderal Pajak tahun 2019 realisasi penerimaan pajak tahun 2014 - 2018 masih dibawah target seperti pada Tabel 1 berikut ini:

Tabel 1 : Realisasi Penerimaan Perpajakan Tahun 2014 - 2018 (dalam trilyun rupiah)

\begin{tabular}{lccccc}
\hline & 2014 & 2015 & 2016 & 2017 & \multicolumn{1}{c}{2018} \\
\hline Target & $1.072,37$ & $1.294,26$ & $1.355,20$ & $1.283,57$ & $1.424,00$ \\
Realisasi & 981,83 & $1.060,83$ & $1.105,81$ & $1.151,03$ & $1.315,51$ \\
\% Capaian & $91,56 \%$ & $81,96 \%$ & $81,60 \%$ & $89,67 \%$ & $92,24 \%$ \\
\hline
\end{tabular}

Sumber : LAKIN DJP tahun 2019

Dari Tabel 1.1 dapat disimpulkan bahwa besaran nilai penerimaan pajak terus mengalami peningkatan setiap tahunnya namun belum sesuai target penerimaan pajak dengan presentasi penerimaan tahun 2014 hingga 2016 cenderung turun namun mulai meningkat pada tahun 2017 dan 2018.

Bagi Negara pajak merupakan sumber pendapatan namun sebaliknya bagi perusahaan pajak merupakan beban yang tentunya akan mengurangi perolehan laba. Adanya perbedaan sudut pandang ini mengakibatkan perusahaan sebagai wajib pajak akan melakukan upaya untuk melakukan penghindaran pajak atau tax avoidance (Dewinta dan Setiawan, 2016). Penghindaran pajak merupakan upaya penghematan pajak yang timbul dengan memanfaatkan ketentuan perpajakan yang dilakukan secara legal untuk meminimalkan kewajiban pajak (Hidayat, 2018). Penghindaran pajak dalam penelitian ini diukur berdasarkan beban pajak kini yang dibayarkan oleh perusahaan (Current ETR).

Oleh karena praktik penghindaran bukan merupakan kegiatan yang menyalahi aturan dan undang - undang perpajakan maka perlu diteliti faktor apa saja yang dapat mempengaruhi perusahaan untuk melakukan atau tidak melakukan praktik penghindaran pajak. Menurut Kusufiyah dan Anggraini (2019) ukuran perusahaan merupakan faktor yang dapat mempengaruhi perusahaan untuk melakukan tindakan penghindaran pajak. Perusahaan dengan skala besar tentu lebih mampu memiliki sumber daya manusia yang lebih kompeten dalam bidangnya termasuk kaitannya pajak. Tujuan utama perusahaan adalah untuk memaksimalkan kemakmuran pemegang saham 
melalui laba yang diperoleh sehingga perusahaan dengan skala besar akan cenderung melakukan praktik penghindaran pajak agar pembayaran pajak dapat seminimal mungkin dan tujuan utama perusahaan memaksimalkan laba dapat tercapai. Berdasarkan hasil penelitian yang dilakukan oleh Swingly dan Sukartha (2015) membuktikan bahwa ukuran perusahaan berpengaruh positif terhadap tindakan penghindaran pajak. Sebaliknya Kusufiyah dan Anggraini (2019) membuktikan dalam penelitiannya bahwa ukuran perusahaan berpengaruh negatif terhadap tindakan penghindaran pajak.

Berdasarkan penelitian yang dilakukan oleh Arianandini dan Ramantha (2018), profitabilitas yang diukur dengan Return On Asset (ROA) merupakan salah satu faktor yang dapat mempengaruhi perusahaan untuk melakukan tindakan penghindaran pajak. ROA merupakan rasio yang digunakan untuk mengukur kemampuan perusahaan dalam menghasilkan laba yang berasal dari aktivitas investasi. Semakin tinggi kinerja ROA perusahaan maka semakin tinggi kemampuan perusahaan dalam menghasilkan laba yang tentu berdampak pada semakin tinggi pula beban pajak yang harus dibayar oleh perusahaan. Oleh karena itu semakin tinggi kinerja ROA perusahaan akan semakin meningkatkan kemungkinan perusahaan untuk melakukan praktik penghindaran pajak.

Faktor keuangan lainnya yang diduga dapat mempengaruhi tindakan penghindaran pajak adalah Debt to Asset Ratio (DAR). DAR merupakan rasio utang yang digunakan untuk mengukur perbandingan antara total utang dengan total aktiva. Dengan penggunaan utang sebagai salah satu sumber dana perusaahan akan diikuti dengan adanya beban bunga yang harus dibayarkan oleh perusahaan. Beban bunga merupakan deductible expense dalam peraturan perpajakan sehingga penggunaan utang akan mampu mengurangi beban pajak yang harus dibayarkan. Hasil penelitian Widyari dan Rasmini (2019) membuktikan bahwa DAR berpengaruh positif terhadap penghindaran pajak, sebaliknya Andy (2018) membuktikan bahwa DAR tidak berpengaruh terhadap penghindaran pajak.

Selain faktor keuangan, faktor non keuangan berupa komite audit juga diduga dapat mempengaruhi perusahaan dalam melakukan praktik penghindaran pajak. Tanggung jawab komite audit dalam good corporate governance (GCG) adalah untuk memastikan bahwa perusahaan telah dijalankan sesuai dengan undang-undang yang berlaku, melaksanakan usahanya dengan beretika, melaksanakan pengawasannya secara 
efektif terhadap benturan kepentingan dan kecurangan yang dilakukan perusahaan. Semakin ketatnya pengawasan yang dilakukan pada suatu manajemen perusahaan maka akan menghasilkan suatu informasi yang berkualitas dan kinerja yang efektif. Karena peran komite audit untuk melakukan pengawasan secara efektif maka sesuai dengan peraturan perundang-undangan sehingga memperkecil kemungkinan terjadinya praktik penghindaran. Hasil penelitian Diantari dan Ulupui (2016) membuktibkan bahwa komite audit berpengaruh negatif terhadap penghindaran pajak sedangkan Damayanti (2015) dalam penelitiannya membuktikan bahwa komite audit tidak berpengaruh terhadap penghindaran pajak.

Penelitian yang membahas faktor-faktor yang berkontribusi terhadap penghindaran pajak telah beberapakali dilakukan sebelumnya namun masih memberikan hasil yang beraneka ragam. Dalam penelitian ini variabel yang diuji bukan hanya variabel terkait keuangan saja namun juga variabel non keuangan berupa komite audit. Tujuan dilakukannya penelitian ini yaitu untuk mengetahui apakah ada pengaruh ukuran perusahaan, return on asset, debt to asset ratio dan komite audit terhadap praktik penghindaran pajak pada perusahaan manufaktur yang terdaftar di Bursa Efek Indonesia (BEI). Adapun periode penelitian yang digunakan adalah periode 2014-2018.

\section{Kajian Literatur dan Hipotesis}

\section{Teori Keagenan}

Teori keagenan digunakan sebagai basis teori dasar praktik bisnis perusahaan selama ini. Teori yang berasal dari sinergi teori ekonomi, teori keputusan, sosiologi, dan teori organisasi. Menurut Prasetya dan Gayatri (2016) asumsi dalam teori keagenan adalah bahwa setiap individu baik principal maupun agent memilki motivasi dan kepentingan yang berbeda sehingga akan mengakibatkan adanya konflik kepentingan diantara mereka yang dapat memunculkan asimetri informasi. Sistem perpajakan yang digunakan di Indonesia adalah self assessment system. Dalam sistem ini perusahaan sebegai agent diberi kesempatan untuk menghitung penghasilan kena pajak serendah mungkin dengan memanfaatkan penghindaran pajak sehingga perusahaan memperoleh keuntungan tersendiri.

\section{Penghindaran Pajak (tax avoidance)}


Menurut Pohan (2015:11) penghindaran pajak merupakan upaya yang dilakukan wajib pajak untuk mengefisiensikan beban pajak yaitu menghindari pengenaan pajak dengan mengarahkannya pada transaksi yang bukan pajak. Metode dan sistem yang diberlakukan adalah dengan menitik beratkan pada kelemahan yang tercantum dalam undang-undang dan peraturan perpajakan. Penghindaran pajak merupakan salah satu strategi yang dapat ditempuh untuk mengefisiensikan beban pajak secara legal. Dalam penelitian ini, penghindaran pajak (tax avoidance) diukur dengan CETR (cash effective tax rate) yaitu pembayaran pajak penghasilan dibagi dengan laba sebelum pajak.

\section{Ukuran Perusahaan}

Ukuran perusahaan dalam penelitian ini diukur dengan total aset yang terdapat didalam perusahaaan. Pendapat ini disebabkan total aset perusahaan cenderung lebih kukuh dibandingkan dengan nilai kapitalisasi pasar dan jumlah penjualan (Siregar dan Widyawati, 2016). Ukuran perusahaan dalam penelitian ini dihitung menggunakan Logaritma Natural dari Total Asset.

\section{Return On Asset (ROA)}

Return On Asset digunakan untuk menghitung kemampuan perusahaan mendapatkan laba dengan menggunakan total asset yang dimiliki perusahaan seusai diselaraskan dengan biaya-biaya untuk membiayai aset tersebut. Menjumlahkan Return On Asset dengan memakai formula laba bersih setelah pajak dibagi dengan total aktiva (Cahyono, Andini dan Raharjo, 2016).

\section{Debt To Asset Ratio (DAR)}

Debt To Asset Ratio adalah salah satu rasio leverage yaitu rasio yang dimanfaatkan untuk menilai perbandingan total utang dengan total aset (Hery, 2016 :166). DAR diukur dengan cara membagi total utang dengan total asset.

\section{Komite Audit}

Menurut Harjadi (2013:117) komite audit bertugas memberikan pendapat professional yang independen kepada dewan komisaris mengenai perihal yang diberikan oleh direksi kepada dewan komisaris serta mengidentifikasi hal-hal yang memerlukan perhatian khusus dewan komisaris. Komite audit dalam penelitian ini diukur dengan 
porsi jumlah komite audit diluar komisaris independen dibagi dengan jumlah komite audit.

Berdasarkan penjelasan diatas maka kerangka teoritis penelitian ini dapat digambarkan sebagai berikut :

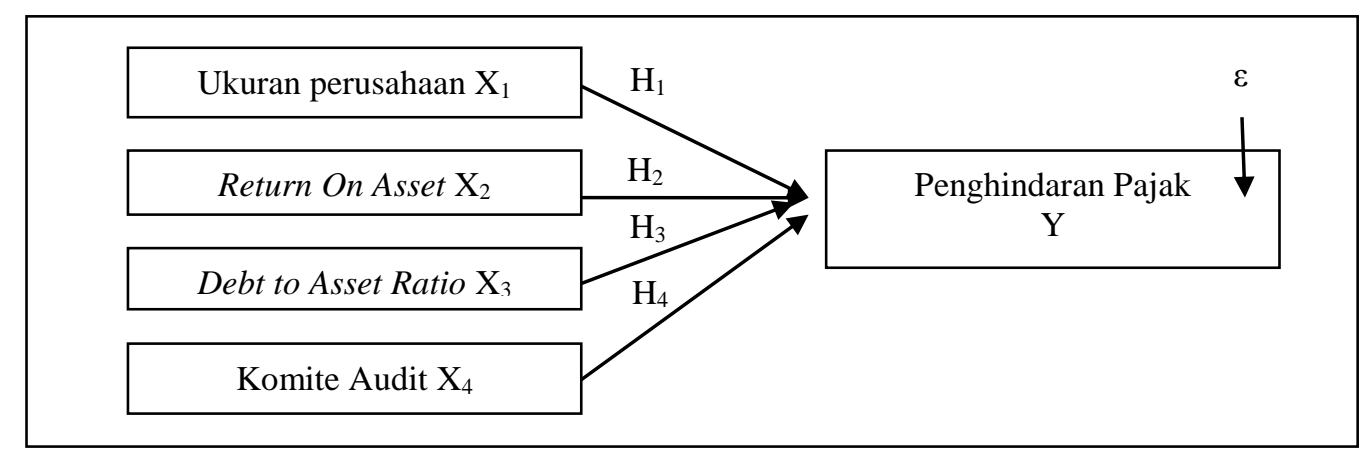

\section{Gambar 1. Kerangka Teoritis Penelitian}

Sumber : Data diolah penulis

\section{Pengembangan Hipotesis}

\section{Pengaruh Ukuran Perusahaan terhadap Penghindaran Pajak}

Menurut Kusufiyah dan Anggraini (2019) perusahaan yang berskala besar mempunyai sumber daya yang lebih kompeten yang dapat digunakan untuk tujuantujuan tertentu. Salah satunya tujuannya yaitu berupaya untuk mengurangi beban pajak yang ditanggung oleh perusahaan. Perusahaan yang besar tentu memiliki banyak sumber daya manusia yang ahli dalam pengelolaan beban pajaknya jika di bandingkan dengan perusahaan kecil. Semakin besar ukuran perusahaan maka semakin tinggi pula kecenderungan untuk melakukan tindakan penghindaran pajak. Berdasarkan uraian tersebut, maka penulis mengajukan hipotesis pertama sebagai berikut :

$\mathrm{H}_{1} \quad$ : Ukuran Perusahaan berpengaruh positif terhadap Penghindaran Pajak

\section{Pengaruh Return on Asset (ROA) terhadap Penghindaran Pajak}

Return on assets adalah salah satu pendekatan yang mampu menunjukan profitabilitas dalam satu perusahaan. Semakin besar tingkat profitabilitas perusahaan maka semakin besar pula laba yang diperoleh perusahaan yang berakibat beban pajak yang ditanggung perusahaan juga meningkat. ROA dan penghindaran pajak akan memiliki hubungan yang positif karena kecenderungan perusahaan adalah untuk 
membayar pajak sekecil - kecilnya. Berdasarkan uraian tersebut, maka penulis mengajukan hipotesis kedua sebagai berikut :

$\mathrm{H}_{2} \quad$ : Return on Assets (ROA) berpengaruh positif terhadap Penghindaran Pajak

\section{Pengaruh Debt to Asset Ratio (DAR) terhadap Penghindaran Pajak}

Utang merupakan dana yang diperoleh dari pihak eksternal. Dalam kaitannya dengan pajak, apabila perusahaan memiliki kewajiban pajak tinggi maka perusahaan akan memiliki utang yang tinggi pula (Saputra dan Asyik, 2017). Oleh sebab itu perusahaan akan berusaha melakukan penghindaran pajak untuk menghindari meningkatnya hutang yang menjadi beban perusahaan. Semakin tinggi tingkat rasio DAR perusahaan maka semakin tinggi pula kecenderungan perusahaan untuk melakukan tindakan penghindaran pajak. Berdasarkan uraian tersebut, maka penulis mengajukan hipotesis keempat sebagai berikut :

$\mathrm{H}_{3} \quad$ : DAR berpengaruh positif terhadap penghindaran pajak

\section{Pengaruh Komite Audit terhadap Penghindaran Pajak}

Komite audit berfungsi untuk membantu dewan komisaris dalam memantau dan mengawasi kinerja manajemen agar sesuai dengan peraturan perundang-undangan yang berlaku. Pengawasan yang efektif agar setiap tindakan yang dilakukan oleh perusahaan sesuai dengan peraturan perundang-undangan akan memperkecil kemungkinan terjadinya praktik penghindaran pajak. Berdasarkan uraian tersebut, maka penulis mengajukan hipotesis kedua sebagai berikut :

$\mathrm{H}_{4} \quad$ : Komite Audit berpengaruh negatif terhadap penghindaran pajak

\section{Metode Penelitian}

\section{Deskripsi Sampel Penelitian}

Populasi yang digunakan dalam penelitian adalah seluruh perusahaan manufaktur yang terdaftar di Bursa Efek Indonesia periode 2014-2018 berjumlah 144 perusahaan. Metode penentuan sampel dengan purposive sampling method, diperoleh 45 sampel perusahaan yang diteliti dengan kriteria sebagai berikut : 
Tabel 1. Ringkasan Perolehan Data Sampel Penelitian

\begin{tabular}{lc}
\hline \multicolumn{1}{c}{ Kriteria } & $\begin{array}{c}\text { Jumlah } \\
\text { Perusahaan }\end{array}$ \\
\hline Perusahaan manufaktur terdaftar di BEI pada tahun 2014-2018 & 144 \\
Perusahaan manufaktur tidak terdaftar secara konsisten selama 2014-2018 & $(45)$ \\
Perusahaan manufaktur yang memiliki kompensasi rugi fiskal periode 2016-2108 & $(54)$ \\
Jumlah perusahaan sampel & 45 \\
Jumlah data sampel (45 perusahaan x 5 tahun periode pengamatan) & 225 \\
\hline Sumber: $\underline{w w}$ w.idx.co.id diolah oleh penulis &
\end{tabular}

\section{Teknik Pengumpulan Data}

Penelitian ini menggunakan teknik dokumentasi dalam memperoleh data yang digunakan. Data diperoleh dari laporan keuangan dan laporan tahunan dengan mengakses website $\underline{w w w . i d x . c o . i d}$

\section{Operasional Variabel}

Tabel 2 : Operasionalisasi Variabel

\begin{tabular}{|c|c|c|}
\hline Variabel & Proksi & Skala \\
\hline 1. Ukuran Perusahaan (Andy, 2018) & SIZE = Ln (Total Asset $)$ & Rasio \\
\hline $\begin{array}{l}\text { 2. Return On Asset } \\
\text { (Cahyono, Andini dan Raharjo, } \\
\text { 2016) }\end{array}$ & $\mathrm{ROA}=\frac{\mathrm{EAT}}{\text { Total Aset }}$ & Rasio \\
\hline $\begin{array}{l}\text { 3. Debt to Asset Ratio } \\
\text { Saputra dan Asyik (2017) }\end{array}$ & DAR $=\frac{\text { Total Utang }}{\text { Total Aset }}$ & Rasio \\
\hline $\begin{array}{l}\text { 4. Komite Audit (Diantari dan } \\
\text { Ulupui, 2016) }\end{array}$ & $\mathrm{KA}=\frac{\sum \text { komite audit diluar komisaris }}{\text { independen }}$ & Rasio \\
\hline 5. Penghindaran Pajak (Andy, 2018) & CETR $=\frac{\text { Current Tax Expense }}{\text { Pretax Income }}$ & Rasio \\
\hline
\end{tabular}

Adapun model regresi linier berganda yang digunakan adalah sebagai berikut:

$Y=a+b_{1} X_{1}+b_{2} X_{2}+b_{3} X_{3}+b_{4} X_{4}+e$

Dimana :

$\begin{array}{lll}\mathrm{Y} & =\text { Penghindaran Pajak } & \mathrm{X}_{2}=\text { Return On Asset } \\ \mathrm{a} & =\text { konstanta } & \mathrm{X}_{3}=\text { Debt to Asset Ratio } \\ \mathrm{b} & =\text { koefisien regresi untuk } \mathrm{X}_{1}, \mathrm{X}_{2}, \mathrm{X}_{3} & \mathrm{X}_{4}=\text { Komite Audit } \\ \mathrm{X}_{1} & =\text { Ukuran Perusahaan } & \mathrm{e}=\text { error }\end{array}$

\section{Hasil dan Pembahasan}




\section{Uji Statistik Deskriptif}

Tabel 3. Hasil Uji Statistik Deskriptif

\begin{tabular}{|l|r|r|r|r|r|}
\hline & $\begin{array}{c}\text { Penghindaran } \\
\text { Pajak } \\
\mathrm{Y}\end{array}$ & $\begin{array}{c}\text { Ukuran } \\
\text { Perusahaan } \\
\mathrm{X}_{1}\end{array}$ & $\begin{array}{c}\text { ROA } \\
\mathrm{X}_{2}\end{array}$ & $\begin{array}{c}\text { DAR } \\
\mathrm{X}_{3}\end{array}$ & $\begin{array}{c}\text { Komite Audit } \\
\mathrm{X}_{4}\end{array}$ \\
\hline Mean & $-0,4906$ & 5,246458 & 2,2592 & 0,476152 & 0,666815 \\
\hline Standar Deviasi & 0,33153 & 0,7102747 & 1,24497 & 0,3464560 & 0,0429848 \\
\hline $\mathrm{N}$ & 225 & 225 & 225 & 225 & 225 \\
\hline
\end{tabular}

Sumber: Olah data hasil SPSS versi 20.0

Tabel Descriptive Statistic di atas merupakan bagian yang berisikan penjelasan dan gambaran dari setiapvariabel, yaitu sebagai berikut: 1). Variabel Penghindaran Pajak (Y) mempunyai mean (rata-rata) sebesar -0,4906 dan Std.Deviation (simpangan baku) sebesar 0,33153 ; 2). Variabel Ukuran Perusahaan (X1) mempunyai mean (ratarata) sebesar 5,246458 dan Std.Deviation (simpangan baku) sebesar 0,7102747; 3). Variabel Return On Asset (X2) mempunyai mean (rata-rata) sebesar 2,2592 dan Std.Deviation (simpangan baku) sebesar 1,24497 ; 4). Variabel Debt to Asset Ratio (X3) mempunyai mean (rata-rata) sebesar 0,476152 dan Std.Deviation (simpangan baku) sebesar 0,3464560 ; 5). Variabel Komite Audit (X4) mempunyai mean (rata-rata) sebesar 0,666815 dan Std.Deviation (simpangan baku) sebesar 0,0429848.

\section{Uji Asumsi Klasik}

\section{Uji Normalitas}

Tabel 4. Hasil Analisis Statistik One Sample Kolmogorov Smirnov

\begin{tabular}{|c|c|c|c|}
\hline & & Unstandardized Residual & Kesimpulan \\
\hline Jumlah Data & & 225 & \multirow{8}{*}{$\begin{array}{c}\text { Nilai sig. } 0,071> \\
0,05 \text { artinya data } \\
\text { berdistribusi } \\
\text { Normal }\end{array}$} \\
\hline \multirow[t]{2}{*}{ Normal Parameters $^{\mathrm{a}, \mathrm{b}}$} & Mean & 0 & \\
\hline & Std. Deviation & 0.29599386 & \\
\hline \multirow[t]{3}{*}{ Most Extreme Differences } & Absolute & 0.086 & \\
\hline & Positive & 0.066 & \\
\hline & Negative & -0.086 & \\
\hline Kolmogorov-Smirnov Z & & 1,292 & \\
\hline Asymp. Sig. (2-tailed) & & 0,071 & \\
\hline
\end{tabular}

Sumber : Olah data hasil SPSS versi 20.0

Berdasarkan pada hasil output nilai sig sebesar 0,071 , nilai tersebut memenuhi ketentuan sig. (p) 0,071 1>0,05 (level of signification) sehingga hipotesis H0 diterima, sedangkan hipotesis Ha ditolak, munujukan data berdistribusi normal. 


\section{Uji Multikolinieritas}

\section{Tabel 5. Hasil Uji Multikolinearitas}

Coefficients $^{\mathrm{a}}$

\begin{tabular}{|l|r|r|l|}
\hline \multicolumn{1}{|c|}{ Variabel } & Tolerance & \multicolumn{1}{c|}{ VIF } & \multicolumn{1}{c|}{ Kesimpulan } \\
\hline Kepemilikan Publik & 0,772 & 1.295 & Tidak terjadi masalah multikolinieritas \\
\hline Leverage (DER) & 0,766 & 1.305 & Tidak terjadi masalah multikolinieritas \\
\hline Lukuiditas (CR) & 0,969 & 1.033 & Tidak terjadi masalah multikolinieritas \\
\hline Kepemilikan Manajerial & 0,950 & 1.053 & Tidak terjadi masalah multikolinieritas \\
\hline
\end{tabular}

Dengan melihat tampilan output Uji Multikolinearitas tabel Coefficients $^{a}$ di atas, diketahui nilai VIF masing-masing variabel sebagai berikut: Ukuran Perusahaan = 1,295, Return On Asset = 1,305, Debt to Asset Ratio = 1,033, Komite Audit = 1,056. Dari hasil output di atas diketahui juga nilai Tolerance masing-masing variabel sebagai berikut : Ukuran Perusahaan $=0,772$, Return On Asset $=0,766$, Debt to Asset Ratio $=$ 0,968, Komite Audit $=0,950$ dari keempat variabel dapat di indikasikan maka tidak terjadi multikolinearitas antar variabel independen.

\section{Uji Autokorelasi}

Tabel 6. Hasil Uji Run Test

\begin{tabular}{|c|c|c|}
\hline & Unstandardized Residual & Kesimpulan \\
\hline Test Value ${ }^{\mathrm{a}}$ & -0.00769 & \multirow{7}{*}{$\begin{array}{l}\text { Nilai Asymp. Sig. (2-tailed) } \\
\text { sebesar } 0,463>0,05 \text { artinya tidak } \\
\text { terjadi autokorelasi dalam data }\end{array}$} \\
\hline Cases $<$ Test Value & 112 & \\
\hline Cases $>=$ Test Value & 113 & \\
\hline Total Cases & 225 & \\
\hline Number of Runs & 108 & \\
\hline $\mathrm{Z}$ & $-0,735$ & \\
\hline Asymp. Sig. (2-tailed) & 0.463 & \\
\hline
\end{tabular}

Dari uji Run Test diatas sebesar 0,463 > 0,05. Maka dapat disimpulkan bahwa dalam penelitian ini dengan menggunakan Uji Run Test data residual random sehingga tidak terjadi autokorelasi (H0 diterima dan Ha ditolak) 


\section{Uji Persamaan Regresi}

Tabel 7. Hasil Analisis Regresi Linear Berganda

Coefficients

\begin{tabular}{|c|c|c|c|c|}
\hline Variabel & Koefisien & t-hitung & Sig. & Kesimpulan \\
\hline (Constant) & 0,531 & 1,542 & 0,124 & Tidak Signifikan \\
\hline Kepemilikan Publik & -0.119 & $-3,708$ & 0,000 & Signifikan \\
\hline Leverage (DER) & -0.131 & $-7,166$ & 0,000 & Signifikan \\
\hline Likuiditas (CR) & 0.005 & 0,87 & 0.931 & Tidak Signifikan \\
\hline $\begin{array}{l}\text { Kepemilikan } \\
\text { Manajerial }\end{array}$ & -0.159 & $-0,334$ & 0.739 & Tidak Signifikan \\
\hline
\end{tabular}

Sumber : Olah data hasil SPSS versi 20.0

Dengan melihat tampilan output Analisis Regresi Linear Berganda tabel coefficients $^{a}$ di atas, maka persamaan regresi yang didapat yaitu sebagai berikut:

$$
Y=0,531-0,119\left(X_{1}\right)-0,131\left(X_{2}\right)+0,005\left(X_{3}\right)-0,159\left(X_{4}\right)+\varepsilon
$$

Keterangan :

$\begin{array}{llll}\mathrm{Y} & =\text { Penghindaran Pajak } & \mathrm{X}_{1} & =\text { Ukuran Perusahaan } \\ \mathrm{a} & =\text { Konstanta } & \mathrm{X}_{2} & =\text { Return on Asset } \\ \varepsilon & =\text { Error } & \mathrm{X}_{3} & =\text { Debt to Asset Ratio } \\ \mathrm{X}_{4} & =\text { Komite Audit } & & \end{array}$

\section{Analisis Koefisien Determinasi (Uji $\mathbf{R}^{2}$ )}

Tabel 8. Hasil Koefisien Determinasi

Model Summary ${ }^{b}$

\begin{tabular}{|c|c|c|c|c|c|}
\hline Model & R & R Square & $\begin{array}{c}\text { Adjusted } \\
\text { R Square }\end{array}$ & $\begin{array}{c}\text { Std. Error of } \\
\text { the Estimate }\end{array}$ & Kesimpulan \\
\hline 1 & $0.450^{\mathrm{a}}$ & 0,203 & 0.188 & 0.29867 & $\begin{array}{c}\text { Persentase kontribusi variabel } \\
\text { independend terhadap terhadap } \\
\text { variabel dependend sebesar 18,8\% }\end{array}$ \\
\hline
\end{tabular}

Sumber: Olah data hasil SPSS versi 20.0

Dengan melihat tampilan output analisis koefisien determinasi tabel Model Summary ${ }^{b}$, Adjusted $R$ Square sebesar 0,188 atau (18,8\%). Koefisien ini menunjukkan bahwa sebesar 18,8\% dari nilai penghindaran pajak perusahaan manufaktur ditentukan oleh (Ukuran Perusahaan, return on asset, debt to asset ratio dan komite audit)Sedangkan sisanya $(81.2 \%),(100 \%-18,8 \%)$. 


\section{Uji Kelayakan Model (Uji F)}

Tabel 9. Hasil Kelayakan Model (Uji F)

\begin{tabular}{|l|r|r|r|c|}
\multicolumn{7}{l|}{ ANOVA $^{\text {a }}$} \\
\hline Model & \multicolumn{1}{c|}{ df } & F-Hitung & F-Tabel & Kesimpulan \\
\hline Regression & 4 & 13,999 & 2,41 & Model Layak \\
\hline Residual & 220 & & & \\
\hline Total & 224 & & & \\
\hline
\end{tabular}

Dengan melihat tampilan output Uji Kelayakan Model (Uji-F) tabel ANOVA ${ }^{b}$, terlihat bahwa tabel $A N O V A^{b}$ atau Uji-F tersebut dapat dilihat yaitu (F $F_{\text {hitung }}$ 13,999 > $\left.F_{\text {tabel }}(0,05,4,225) 2,41\right)$. Sedangkan dengan menggunakan nilai signifikannya yaitu sebesar $(\operatorname{Sig} 0,00<\operatorname{Sig} 0,05)$

\section{Interpretasi Hasil Penelitian}

\section{Pengaruh Ukuran Perusahaan terhadap Penghindaran Pajak}

Hasil uji t pada Tabel 8 menunjukkan bahwa variabel ukuran perusahaan memiliki nilai koefisien jalur bertanda negatif sebesar $-3,708$ dan nilai Sig yang diperoleh adalah sebesar 0,000 yang berarti bahwa H1 diterima karena memiliki nilai Sig lebih kecil dari 0,05 sehingga dapat disimpulkan bahwa variabel ukuran perusahaan (X1) berpengaruh negatif dan signifikan terhadap penghindaran pajak. Hal tersebut mengindikasikan bahwa perusahaan tidak menggunakan sumber daya yang dimilikinya untuk mengelola pajaknya karena perusahaan dengan skala besar cenderung menjadi perhatian fiskus sehingga banyak batasan untuk melakukan penghindaran pajak. Hasil penelitian ini konsisten dengan hasil penelitian Widyari dan Rasmini (2019) yang membuktikan bahwa ukuran perusahaan berpengaruh negatif terhadap penghindaran pajak.

\section{Pengaruh Return on Asset terhadap Penghindaran Pajak}

Hasil uji t pada Tabel 8 menunjukkan bahwa variabel return on asset memiliki nilai koefisien jalur bertanda negatif sebesar -7,166 dan nilai Sig yang diperoleh adalah sebesar 0,000 yang berarti bahwa $\mathrm{H} 2$ diterima karena memiliki nilai Sig lebih kecil dari 0,05 sehingga dapat disimpulkan bahwa variabel return on asset (X2) berpengaruh negatif dan signifikan terhadap penghindaran pajak. Dari hasil ini dapat diartikan bahwa semakin tinggi nilai ROA maka semakin tinggi keuntungan perusahaan sehingga semakin baik pengelolaan aset suatu perusahaan untuk memperoleh laba. Kinerja 
manajemen yang baik dalam menghasilkan laba akan memotivasi perusahaan untuk melakukan perencanaan pajak dengan lebih baik sehingga praktik penghindaran pajak akan menurun. Hasil penelitian ini didukung oleh Kusufiyah dan Anggraini (2019) yang mengemukakan bahwa Return On Asset berpengaruh negatif terhadap Penghindaran Pajak

\section{Pengaruh Debt to Asset Ratio terhadap Penghindaran Pajak}

Hasil uji t pada Tabel 8 menunjukkan bahwa variabel debt to asset ratio memiliki nilai koefisien jalur bertanda positif sebesar 0,087 dan nilai Sig yang diperoleh adalah sebesar 0,931 yang berarti bahwa H3 ditolak karena memiliki nilai Sig lebih besar dari 0,05 sehingga dapat disimpulkan bahwa variabel debt to asset ratio (X3) tidak berpengaruh terhadap penghindaran pajak. Debt to Asset Ratio tidak berpengaruh terhadap penghindaran pajak karena perusahaan tidak menggunakan hutang untuk meminimalisir atau mengurangi beban pajak tetapi untuk membiayai operasional perusahaan. Hasil penelitian ini didukung oleh Anindyka, Pramoto dan Kurnia (2018) mengemukakan bahwa Debt to Asset Ratio tidak berpengaruh terhadap penghindaran pajak.

\section{Pengaruh Komite Audit terhadap Penghindaran Pajak}

Hasil uji t pada Tabel 8 menunjukkan bahwa variabel debt to asset ratio memiliki nilai koefisien jalur bertanda negatif sebesar -0,334 dan nilai Sig yang diperoleh adalah sebesar 0,739 yang berarti bahwa $\mathrm{H} 4$ ditolak karena memiliki nilai Sig lebih besar dari 0,05 sehingga dapat disimpulkan bahwa variabel komite audit (X4) tidak berpengaruh terhadap penghindaran pajak. Peran komite audit adalah melakukan pengawasan dan pengontrolan terhadap proses kontrol internal dan pelaporan keuangan. Hal ini mengindikasikan bahwa kinerja komite audit tidak sesuai ekpektasi meskipun anggota komite audit telah sesuai dengan yang disyaratkan BEI yaitu minimal 3 orang. Hasil penelitian ini didukung oleh penelitian sebelumnya yaitu Swingly dan Sukharta (2015), yang mengemukakan bahwa komite audit tidak berpengaruh terhadap penghindaran pajak. 


\section{Kesimpulan}

Penelitian ini bertujuan untuk mengetahui pengaruh ukuran perusahaan, return on asset, debt to asset ratio dan komite audit terhadap penghindaran pajak. Berdasarkan hasil penelitian yang telah diuraikan diatas maka kesimpulan yang dapat diberikan sebagai berikut : 1). Ukuran Perusahaan berpengaruh negatif terhadap penghindaran pajak artinya semakin besar aset yang dimiliki perusahaan maka semakin rendah praktik penghindaran pajak yang dilakukan perusahaan ; 2). Return on Asset berpengaruh negatif terhadap Penghindaran Pajak artinya semakin tinggi kemampuan perusahaan menghasilkan laba menggunakan aset yang dimilikinya maka semakin rendah praktik penghindaran pajak yang dilakukan perusahaan; 3). Debt to Asset Ratio tidak berpengaruh terhadap Penghindaran Pajak artinya semakin tinggi nilai pendanaan ekternal yang digunakan oleh perusahaan tidak mempengaruhi tindakan perusahaan untuk melakukan penghindaran pajak; 4). Komite Audit tidak berpengaruh terhadap penghindaran pajak, hal ini bisa disebabkan karena penghindaran pajak merupakan upaya legal untuk meminimalkan pembayaran pajak sehingga dengan meningkatnya jumlah komite audit tidak berpengaruh terhadap praktik penghindaran pajak. 


\section{Referensi}

Andy. (2018). Pengaruh return on assets, debt to equity ratio, debt to assets ratio, ukuran perusahaan dan deferred tax expense terhadap tax avoidance. Jurnal Ekonomi Dan Bisnis - Vol. 16. No. 2, hal 42-53, ISSN:412-632X (Printed)| 2614-6789 (Online)

Anindyka, D., Pratomo, D., \& Kurnia. (2018). Pengaruh leverage (dar), capital intensity, dan inventory intensity terhadap tax avoidance. E-Proceeding of Management, 5(1), hal. 713-719.

Arianandini, P. W., \& Ramantha, I.W. (2018). Pengaruh profitabilitas, leverage dan kepemilikan institusional pada tax avoidance. E-Jurnal Akuntansi Universitas Udayana Vol. 22.3, hal. 2107, ISSN : 2088-2116.

Cahyono, D.D., Andini, R., \& Raharjo, K. (2016). Pengaruh komite audit, kepemilikan institusional, dewan komisaris, ukuran perusahaan (size), leverage (der) dan profitabilitas (roa) terhadap tindakan penghindaran pajak (tax avoidance) pada perusahaan perbankan yang listing bei periode tahun 2011 - 2013. Jurnal Ilmiah Mahasiswa S1 Akuntansi Universitas Pandanaran Vol 2, No 2.

Damayanti (2015). Pengaruh komite audit, kualitas audit, kepemilikan insitusional, return on assets terhadap tax avoidance. Jurnal Bisnis dan Manajemen, Vol. 5 No. 2, hal. 187-206

Dewinta, I.A.R., \& Setiawan, P.E. (2013). Pengaruh ukuran perusahaan, profitabilitas, leverage, dan pertumbuhan penjualan terhadap tax avoidance. E-Jurnal Akuntansi Universitas Udayana Vol. 14.3, hal. 1584-1613, ISSN : 2302-8556

Diantari, P. R., \& Ulupui, I.G.K.A. (2016). Pengaruh komite audit, proporsi komisaris independen, dan proporsi kepemilikan institusional terhadap tax avoidance. $E$ Jurnal Akuntansi, [S.l.], Vol. 16, No. 1, hal. 702-732, ISSN 2302-8556.

Harjadi, S. 2013. Pasar Modal Indonesia Pengantar dan Analisis. Jakarta :In Media

Hery. (2016). Analisis Laporan Keuangan, Integrated and Comprehensive Edition. Jakarta: PT Grasindo.

Hidayat, W. (2018). Pengaruh profitabilitas, leverage dan pertumbuhan penjualan terhadap penghindaran pajak. Jurnal Riset Manajemen Dan Bisnis (JRMB) Fakultas Ekonomi UNIAT, 3 (1), hal. 19-26. https://doi.org/10.36226/jrmb.v3i1.82

Kusufiyah, Y. V., \& Anggraini, D. (2019). Peran komisaris independen, ukuran perusahaan, kinerja keuangan dan leverage terhadap usaha penghindaran pajak. E-Jurnal Akuntansi, [S.l.], Vol. 26, No. 2, hal. 1601-1631. ISSN 2302-8556.

Pohan,. \& Anwar, C. 2015. Manajemen perpajakan strategi perencanaan pajak dan bisnis. Jakarta : PT. Gramedia Pustaka Utama

Prasetya, P.J., \& Gayatri. (2016). Pengaruh ukuran perusahaan terhadap manajemen laba dengan pengungkapan corporate social responsibility sebagai variabel intervening. E-Jurnal Akuntansi Universitas Udayana Vol. 14.1, hal. 511-538. ISSN: 2303-1018. 
Saputra, M. D. R., \& Asyik, N. S. (2017). Pengaruh profitabilitas, leverage, dan corporate governance terhadap tax avoidance. Jurnal Ilmu dan Riset Akuntansi, Volume 6, Nomor 8.

Siregar, R., \& Widyawati, D. (2016). Pengaruh karakterisktik perusahaan terhadap penghindaran pajak pada perusahaan manufaktur di bei. Jurnal Ilmu dan Riset Akuntansi, Vol. 5, No. 2, STIESIA : Surabaya

Swingly, C., \& Sukartha, I.M. (2015). Pengaruh karakter eksekutif, komite audit, ukuran perusahaan, leverage dan sales growth terhadap tax avoidance. E-Jurnal Akuntansi, Vol. 10, No. 1, hal. 47-62. ISSN 2302-8556.

Widyari, N.Y.A., \& Rasmini, N.K. (2019). Pengaruh kualitas audit, size, leverage, dan kepemilikan keluarga pada agresivitas pajak. E-Jurnal Akuntansi Universitas Udayana Vol.27, No. 1, hal. 388-417. ISSN: 2302-8556 DOI: https://doi.org/10.24843/EJA.2019.v27.i01.p15

Direktorat Jenderal Pajak. (2019). Laporan Kinerja Direktorat Jenderal Pajak tahun 2019. 